

Publisher

http://jssidoi.org/esc/home

\title{
REVIEW OF THE EGYPT SCIENCE AND TECHNOLOGY SYSTEM; SWOT ANALYSIS
}

\author{
Amr Radwan', Mahmoud Sakr ${ }^{2 *}$ \\ ${ }^{1,2}$ Academy of scientific research and technology, 101 Kasr Al-Ainy street, 11516, Cairo, Egypt \\ E-mails:1radwan.amro@gmail.com; ${ }^{2}$ msakr@asrt.sci.eg
}

Received 18 June 2017; accepted 10 October 2017; published 29 December 2017

\begin{abstract}
In this review, we conduct an exploratory study to assess Egypt Science and Technology System by the utilization of the Delphi survey combined with "Electronic Town Meeting" protocol following a preliminary evaluation of research and innovation performance at the national level. The application of this protocol was directed toward a realization of national science and technology SWOT analysis. Within this analytical framework, we examined different components of Egypt Science and Technology System in addition to competencies, bottlenecks and opportunities with the aim of providing a concrete assessment view and draw useful directions that could be rapidly utilized in different settings. We recommend using this combined protocol in the different strategic planning settings and actions.
\end{abstract}

Keywords: Science and Technology, SWOT analysis, research assessment, innovation system.

Reference to this paper Radwan, A.; Sakr, M. 2017. Review of Egypt Science and Technology System Entrepreneurship and Sustainability Issues 5(2): 204- 211. http://doi.org/10.9770/jesi.2017.5.2(3)

JEL Classifications: $\mathrm{O} 1 ; \mathrm{O} 3$

Additional disciplines: political sciences; sociology

\footnotetext{
* This research was supported by the project, which has received funding from the European Union's Horizon 2020 research and innovation programme European Research Council (ERC) under the European Union's Horizon 2020 research and innovation programme Marie Sklodowska-Curie Research and Innovation Staff Exchanges ES H2020-MSCA-RISE-2014 CLUSDEVMED (2015-2019) Grant Agreement Number 645730730
}
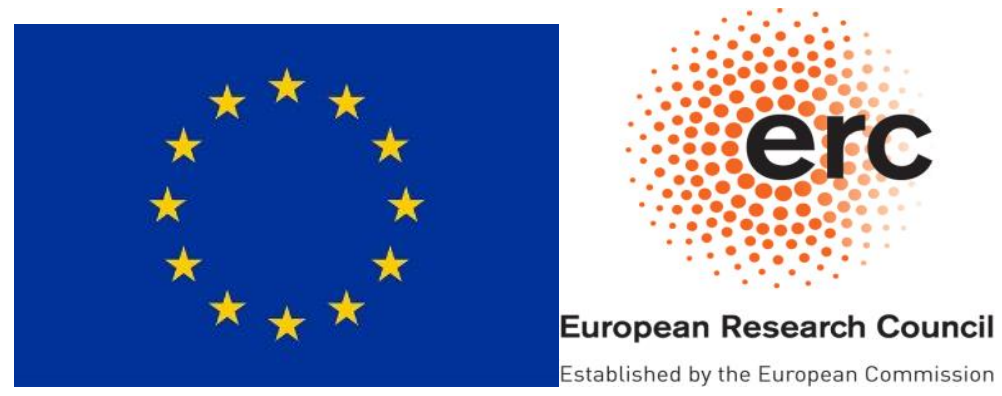


\section{Introduction}

The differences in science and technology systems are prominent among developing countries and between developed and developing countries (O’Brien et al., 2013; Melas et al., 2017; Tvaronavičienė et al., 2017; Štiglic, 2017).

The recent dynamics following the Arab spring in the North African region implied further developments in the national system of science and technology. Several countries in this region exerted a lot of efforts in reviewing and revisiting current legislations, policies and strategies (Etzkowitz \& Leydesdorff, 2000). An increased focus in the measures to optimize the research and innovation performance at the national level became a central component of national strategies (Bermejo Ruiz \& De Pablos-Heredero, 2013a; Ghinolfi et al., 2014). In this respect, assessing the current system and structures became a paramount and prerequisite for any development plan (Ghinolfi et al., 2014). The analysis of strength, weakness, opportunities and threads (SWOT) is a commonly conducted analysis and defined as comprehensive method to study the system environment (Phadermrod, Crowder, \& Wills, 2016). SWOT has been used extensively to assess industries and has been also used recently to assess national systems for science and technology (Bermejo Ruiz \& De Pablos-Heredero, 2013b). Although the importance of such assessment, few attempts were done in the North African region. Several computing analytical techniques were used to engage stakeholders in the strategic planning process and the use of electronic town meeting (ETM) protocol has evolved quickly since it was firstly introduced in late 1990s when it was used in the USA for engaging citizens and different stakeholders in the policy planning process (Becker, 2001). It was demonstrated that electronic town meetings could be used widely in Science, Technology and Innovation planning process (George, Nunamaker Jr, \& Valacich, 1992). In this respect, the aim of this analysis is to analyze the national science and technology system in Egypt and visualize the research and innovation landscape from a wide strategic angle.

\section{Research Methodology}

\subsection{Study framework}

This assessment was done through two phases; the first phase includes the creation of theoretical-methodological corpus based on primary and secondary sources in the fields research and innovation performance. Based on the findings of the first phase, an exploratory research study was performed using Delphi technique combined with electronic town meeting protocol in constructing SWOT analysis. Benefiting from the grounded theory, an iterative process has been conducted in each round of surveys and the last inputs were captured while considering the majority consensus (Charmaz \& Bryant, 2010). The theoretical-methodological corpus was used to define a set of indicators including "operational indicators", "performance indicators" and "functional indicators". The questionnaire design followed Oslo Manual of OECD and a short version has been produced to reflect the correlation of the identified indicators with policies, strategies and technological roadmaps (Organisation for Economic \& Development, 2010).

\section{The SWOT analysis consisted of three phases}

1. Selection of analytical parameters;

2. Data collection; and

3. Analysis and reporting.

\section{SWOT analytical parameters}

Based on the theoretical methodological corpus, we have used the confrontation matrix model in selecting the analytical parameters of the SWOT analysis (Kearns, 1992). These parameters include:

- Human resources Capacity

- Research infrastructure

- Funding

- Regulations and legislation system 
ENTREPRENEURSHIP AND SUSTAINABILITY ISSUES

ISSN 2345-0282 (online) http://jssidoi.org/jesi/

2017 Volume 5 Number 2 (December)

http://doi.org/10.9770/jesi.2017.5.2(3)

- Local innovation ecosystem

- International prospective

- $\quad$ Utilization of IPR and research investments

\subsection{Data collection and analysis}

The application of the Delphi method has been deployed in this assessment based in two questionnaires. Each parameter was analyzed with multiple questions through the distribution of semi-quantitative, and qualitative questionnaires. The articulation of the investigational points was addressing the main drivers, challenges, obstacles and opportunities facing the science and technology system in Egypt with specific emphasis on facilitating the articulation of relevant recommendations.

The generated responses were organised through "Electronic Town Meeting" (ETM) protocol (Becker, 2001). ETM is a community meeting that allows people to participate and interact via digital technology to influence decision-making processes (George, Nunamaker, \& Valacich, 1992). Participants were invited to fill the questionnaire and participate afterwards in a group discussion. Interaction and exchange of ideas between the different groups is facilitated by a real-time transcription system that allows sending the results of each group discussion to a theme coordinator who is responsible of delivering an instant report few minutes after the end of a round of discussion. Furthermore, electronic survey tools were used to integrate discussions so that participants can further validate the group answers. The discussions results are presented during the same day for an additional round of inputs and a majority consensus is realised through an electronic polling system. Participants were then invited to fill individually the second questionnaire following the same process. This state of the art methodology helped all participants to actively participate in a democratic way where all ideas are instantly captured, thus concrete results are produced.

Data collection was done through the organisation of two ETMs where each has 100 invited experts. To have a representative sample, experts were carefully selected to present all stakeholders where a quarter of all participants represented industry, and 40\% represented equal participation from universities and research institutions, while Technology Transfer offices were represented by $15 \%$, and each of local authorities, international agencies, media and scientific journalists, and civil societies was represented by $5 \%$.

Questionnaires were answered according to participants' expertise, knowledge, and involvement in the innovation ecosystem activities. Qualitative answers were counted as positive (strength) or negative (weakness), semiquantitative answers received a score ranging from one (maximum weakness) to five (maximum strength). Questionnaires contained a total of 54 questions, 32 of which were enclosed in the internal factor analysis and 22 in the external factor analysis.

\section{Reporting of findings}

Table 1. Strengths and weakness of the national science and technology system

\begin{tabular}{c|l|l} 
& \multicolumn{1}{|c}{ Strength points } & \multicolumn{1}{c}{ Weakness Points } \\
\hline \multirow{4}{*}{ Human } & $\begin{array}{l}\text { Availability of good research base of more than } \\
100,000 \text { research, 50 universities, 120 research } \\
\text { centers and growing number of civil societies with } \\
\text { supportive role to Science and Technology }\end{array}$ & $\begin{array}{l}\text { Poor distribution of researchers' headcount in } \\
\text { relevance to available competencies }\end{array}$ \\
\cline { 2 - 3 } & $\begin{array}{l}\text { Research community in Egypt is highly productive, } \\
\text { as indicated by publications' count in the last 10 } \\
\text { years. }\end{array}$ & $\begin{array}{l}\text { Full time equivalent researchers don't constitute } \\
\text { more than 45\% of the total count of researchers }\end{array}$ \\
\cline { 2 - 3 } & Large number of qualified scholars in diaspora. & $\begin{array}{l}\text { Low number of qualified supporting staff in } \\
\text { higher education establishments in addition to } \\
\text { poor availability of skilled technicians }\end{array}$ \\
\cline { 2 - 3 } & Active international mobility of young scholars. & $\begin{array}{l}\text { Low number of effective mechanisms for } \\
\text { empowering and engaging young scholars in }\end{array}$
\end{tabular}




\begin{tabular}{|c|c|c|}
\hline \multirow{4}{*}{$\begin{array}{l}\text { resources' } \\
\text { Capacity }\end{array}$} & & planning. \\
\hline & \multirow{3}{*}{$\begin{array}{l}\text { Population demographic pattern shows a great } \\
\text { potential for wide spectrum of development with } \\
\text { the existence of large percentage of young. }\end{array}$} & $\begin{array}{l}\text { Poor recruitment structure in hiring well } \\
\text { qualified scholars (and not only own graduates). }\end{array}$ \\
\hline & & $\begin{array}{l}\text { Routine career path of researchers that is not } \\
\text { incentivized enough with regard to excellence in } \\
\text { science and technology. }\end{array}$ \\
\hline & & $\begin{array}{l}\text { Low number of scientists in physics and } \\
\text { mathematics when compared other disciplines }\end{array}$ \\
\hline \multirow{7}{*}{$\begin{array}{l}\text { Infrastructu } \\
\text { re }\end{array}$} & $\begin{array}{l}\text { Availability of good physical networks and } \\
\text { connectivity of research institutions in Egypt }\end{array}$ & $\begin{array}{l}\text { Lack of national programs for assessing and } \\
\text { upgrading of research facilities. }\end{array}$ \\
\hline & $\begin{array}{l}\text { Availability of scientific databases, digital libraries } \\
\text { and data management applications }\end{array}$ & \multirow{2}{*}{$\begin{array}{l}\text { Most of the private universities have poor R\&D } \\
\text { infrastructure and thus, are not qualified enough } \\
\text { to conduct significant R\&D projects. }\end{array}$} \\
\hline & \multirow{2}{*}{$\begin{array}{l}\text { High bandwidth internet connectivity that support } \\
\text { research applications }\end{array}$} & \\
\hline & & $\begin{array}{l}\text { Less awareness about the existence of high } \\
\text { qualified facilities and labs. }\end{array}$ \\
\hline & $\begin{array}{l}\text { Numerous specialized research networks including } \\
\text { high energy physics, nanotechnology, nuclear } \\
\text { research and viral hepatitis C. }\end{array}$ & $\begin{array}{l}\text { Lack of comprehensive inventory of all available } \\
\text { infrastructure regarding functions, specs, } \\
\text { maintenance log and expected lifetime }\end{array}$ \\
\hline & $\begin{array}{l}\text { Good distribution of functional equipment across } \\
\text { universities and research centers }\end{array}$ & $\begin{array}{l}\text { Poor accessibility and use of existing } \\
\text { infrastructure in public research institutions. }\end{array}$ \\
\hline & $\begin{array}{l}\text { Establishment of new private research centers, } \\
\text { especially in the medical field. }\end{array}$ & $\begin{array}{l}\text { Low number of excellence centers in Science } \\
\text { and Technology }\end{array}$ \\
\hline \multirow[t]{4}{*}{ Funding } & Diversified mechanisms of public funding on R\&D. & $\begin{array}{l}\text { National funding of Scientific research is highly } \\
\text { fragmented. }\end{array}$ \\
\hline & $\begin{array}{l}\text { Allocation of more than } 1,000,000 \text { euros annually } \\
\text { for scientific missions abroad. }\end{array}$ & $\begin{array}{l}\text { Lack of effective evaluation and monitoring } \\
\text { scheme of the different funding schemes and } \\
\text { accordingly, the economic and technological } \\
\text { impact. }\end{array}$ \\
\hline & \multirow{2}{*}{$\begin{array}{l}\text { Gradual increase in public expenditure on research } \\
\text { and development which shall reach 1\% of GDP } \\
\text { according to Egypt constitution. }\end{array}$} & $\begin{array}{l}\text { Business expenditure in R\&D is lower than } \\
\text { expected average and insufficient. }\end{array}$ \\
\hline & & $\begin{array}{l}\text { The lack of sufficient skills in writing } \\
\text { competitive proposals or managing collaborative } \\
\text { research and innovation projects. }\end{array}$ \\
\hline \multirow[t]{3}{*}{$\begin{array}{l}\text { Regulations } \\
\text { and } \\
\text { legislation } \\
\text { system }\end{array}$} & $\begin{array}{l}\text { National R\&D funding increase to } 1 \% \text { of GDP } \\
\text { according to the new national constitution. This is } \\
\text { the first time this has been stipulated in an Egyptian } \\
\text { Constitution. }\end{array}$ & $\begin{array}{l}\text { The existence of national laws that prohibits } \\
\text { research organizations to establish spin-off } \\
\text { companies }\end{array}$ \\
\hline & \multirow{2}{*}{$\begin{array}{l}\text { Boosting the capacities of the national system with } \\
\text { new entities like the presidential council for } \\
\text { scientific research in addition to activating the } \\
\text { supreme council of research. }\end{array}$} & $\begin{array}{l}\text { Lack of specific regulations in particular } \\
\text { domains like clinical research and clinical trials. }\end{array}$ \\
\hline & & $\begin{array}{l}\text { Significant rate of research plagiarism at the } \\
\text { national level with insignificant preventive } \\
\text { regulations. }\end{array}$ \\
\hline \multirow[t]{4}{*}{$\begin{array}{l}\text { Innovation } \\
\text { ecosystem }\end{array}$} & $\begin{array}{l}\text { Growing number of actors in the innovation } \\
\text { ecosystem including business competitions, venture } \\
\text { capitalists, incubators and specialized civil } \\
\text { societies. }\end{array}$ & $\begin{array}{l}\text { More focus at the national level on Information } \\
\text { and communication Technologies and less } \\
\text { emphasis on other technological areas. }\end{array}$ \\
\hline & $\begin{array}{l}\text { A recently established system for monitoring and } \\
\text { evaluation of research and innovation at the } \\
\text { national level. }\end{array}$ & $\begin{array}{l}\text { Lack of an effective national strategy for } \\
\text { research and innovation. Existing technology } \\
\text { roadmaps and strategies are not binding to the } \\
\text { relevant actors. No sufficient incentives that } \\
\text { could encourage the implementation of national } \\
\text { strategies. }\end{array}$ \\
\hline & $\begin{array}{l}\text { Growing number of initiatives and programs that } \\
\text { focus on raising scientific culture and } \\
\text { popularization of sciences. }\end{array}$ & $\begin{array}{l}\text { No significant coordination measure among } \\
\text { public innovation support organisations. }\end{array}$ \\
\hline & $\begin{array}{l}\text { New schemes for public private partnerships and } \\
\text { technology alliances. }\end{array}$ & $\begin{array}{l}\text { Primary focus at the institutional settings on } \\
\text { research excellence based on the constricted and } \\
\text { routine definition with regard to the production } \\
\text { of knowledge rather than the use of knowledge. }\end{array}$ \\
\hline
\end{tabular}


ENTREPRENEURSHIP AND SUSTAINABILITY ISSUES

ISSN 2345-0282 (online) http://jssidoi.org/jesi/

2017 Volume 5 Number 2 (December)

http://doi.org/10.9770/jesi.2017.5.2(3)

\begin{tabular}{|c|c|c|}
\hline & & $\begin{array}{l}\text { Routine workflow of the governmental sector } \\
\text { that doesn't encourage research and innovation } \\
\text { practice. }\end{array}$ \\
\hline & & $\begin{array}{l}\text { Low interest in socioeconomic studies with less } \\
\text { significant funding or supporting scheme. }\end{array}$ \\
\hline \multirow[t]{3}{*}{$\begin{array}{l}\text { Internationa } \\
\qquad 1 \\
\text { perspective }\end{array}$} & $\begin{array}{l}\text { High scientific productivity in the fields of } \\
\text { Chemistry, Medicine, material sciences. High } \\
\text { impact of scientific fields like mathematics, physics } \\
\text { and agriculture. }\end{array}$ & Low rank in the global innovation index. \\
\hline & \multirow[t]{2}{*}{$\begin{array}{l}\text { Ongoing efforts in indexing local scientific journals } \\
\text { in the international publishers' databases. }\end{array}$} & $\begin{array}{l}\text { Insignificant impact of the public and } \\
\text { International relations offices in public research } \\
\text { institutions }\end{array}$ \\
\hline & & $\begin{array}{l}\text { Lack of internationalization strategy at the level } \\
\text { of institutions. }\end{array}$ \\
\hline \multirow{3}{*}{$\begin{array}{l}\text { The use of } \\
\text { Intellectual } \\
\text { property } \\
\text { rights and } \\
\text { research } \\
\text { investments }\end{array}$} & $\begin{array}{l}\text { Existence of technology transfer and IPR offices at } \\
\text { the majority of Egyptian universities. }\end{array}$ & $\begin{array}{l}\text { Economic return of Egypt intellectual property } \\
\text { rights is weak. }\end{array}$ \\
\hline & \multirow[t]{2}{*}{$\begin{array}{l}\text { Existence of many public initiatives to transform } \\
\text { research results into economic value. }\end{array}$} & $\begin{array}{l}\text { Low number of patents' files and awarded } \\
\text { patents. }\end{array}$ \\
\hline & & $\begin{array}{l}\text { Lack of IP and patents' portfolio analysis at the } \\
\text { national and institutional levels. }\end{array}$ \\
\hline
\end{tabular}

Table 2. Opportunities and threats of the national science and technology system

\begin{tabular}{|c|c|c|}
\hline & Opportunities & Threats \\
\hline \multirow{4}{*}{$\begin{array}{l}\text { Human } \\
\text { resources' } \\
\text { capacity }\end{array}$} & $\begin{array}{l}\text { Ongoing growth rate of number of researchers in } \\
\text { different disciplines }\end{array}$ & $\begin{array}{l}\text { Gender imbalance in vertical and horizontal } \\
\text { segregation of women's in science. }\end{array}$ \\
\hline & $\begin{array}{l}\text { Significant percentage of young researchers among } \\
\text { the total research population }\end{array}$ & $\begin{array}{l}\text { Research and education are greatly dominated by } \\
\text { the public sector }\end{array}$ \\
\hline & $\begin{array}{l}\text { Existence of well-trained experts in research } \\
\text { investment and funding, indicators and evaluation }\end{array}$ & $\begin{array}{l}\text { Misuse of the potentiality of human resources; } \\
\text { repetition and overlap of several research } \\
\text { activities at the national level. }\end{array}$ \\
\hline & $\begin{array}{l}\text { Thousands of Egyptian experts abroad with high } \\
\text { scientific capabilities and industrial experience. }\end{array}$ & $\begin{array}{l}\text { Extensive Brain drain towards gulf area and } \\
\text { some European countries. }\end{array}$ \\
\hline \multirow{4}{*}{$\begin{array}{l}\text { Research } \\
\text { infrastructu } \\
\text { re }\end{array}$} & $\begin{array}{l}\text { Existence of number of centers of excellence } \\
\text { located in different governorates }\end{array}$ & $\begin{array}{l}\text { Research infrastructure is very concentrated in } \\
\text { Cairo and delta region }\end{array}$ \\
\hline & $\begin{array}{l}\text { Political support in establishments of science parks } \\
\text { and new science cities. }\end{array}$ & $\begin{array}{l}\text { Research expertise distribution is indirectly } \\
\text { proportional to the existence of good } \\
\text { infrastructure }\end{array}$ \\
\hline & $\begin{array}{l}\text { Egypt membership in many international scientific } \\
\text { and technological networks and unions. }\end{array}$ & $\begin{array}{l}\text { Research activities not oriented to businesses' } \\
\text { needs in addition to less utilization of existing } \\
\text { capabilities. }\end{array}$ \\
\hline & $\begin{array}{l}\text { Wealth of equipment distributed widely among } \\
\text { research centers and universities. }\end{array}$ & $\begin{array}{l}\text { Lack of financial tools that support the upgrading } \\
\text { and acquisition of research and innovation } \\
\text { equipment. }\end{array}$ \\
\hline \multirow[t]{3}{*}{ Funding } & $\begin{array}{l}\text { Existence of diversified public funding of basic and } \\
\text { applied research }\end{array}$ & $\begin{array}{l}\text { Routine research administration and its effect on } \\
\text { institutional competitiveness in the international } \\
\text { funding programs. }\end{array}$ \\
\hline & \multirow[t]{2}{*}{ Increasing public $R \& D$ expenditure } & $\begin{array}{l}\text { Market dominated by big enterprises with the } \\
\text { significant presence of informal sector }\end{array}$ \\
\hline & & $\begin{array}{l}\text { No sufficient program to leverage resources and } \\
\text { engage SMEs in } R \& D \text { activities in cooperation } \\
\text { with academia. }\end{array}$ \\
\hline \multirow{2}{*}{$\begin{array}{l}\text { Regulations } \\
\text { and } \\
\text { legislations }\end{array}$} & $\begin{array}{l}\text { Existence of many initiatives and projects to revisit } \\
\text { laws including research incentive law. }\end{array}$ & $\begin{array}{l}\text { Excessive changes within the national innovation } \\
\text { system. }\end{array}$ \\
\hline & $\begin{array}{l}\text { Increase utilization of IPR policies in universities } \\
\text { and research centers. }\end{array}$ & $\begin{array}{l}\text { The lack of enforcement to policies with unclear } \\
\text { incentive scheme to encourage research }\end{array}$ \\
\hline
\end{tabular}


ENTREPRENEURSHIP AND SUSTAINABILITY ISSUES

ISSN 2345-0282 (online) http://jssidoi.org/jesi/

2017 Volume 5 Number 2 (December)

http://doi.org/10.9770/jesi.2017.5.2(3)

\begin{tabular}{|c|c|c|}
\hline & & $\begin{array}{l}\text { performers to consider the local and national } \\
\text { polices. }\end{array}$ \\
\hline & $\begin{array}{l}\text { Clear pathway and system for introducing new law, } \\
\text { specific amendments and regulation }\end{array}$ & $\begin{array}{l}\text { Legislative obstacles that decrease the flow of } \\
\text { technology and know-how transfer. }\end{array}$ \\
\hline \multirow[t]{8}{*}{$\begin{array}{l}\text { Innovation } \\
\text { ecosystem }\end{array}$} & $\begin{array}{l}\text { Growing capacities of several actors in the } \\
\text { innovation ecosystem including non-governmental } \\
\text { organizations }\end{array}$ & $\begin{array}{l}\text { The independence perception of universities and } \\
\text { public research performers. }\end{array}$ \\
\hline & $\begin{array}{l}\text { Growing number of institutional policy } \\
\text { development }\end{array}$ & Education reform resistance \\
\hline & $\begin{array}{l}\text { Significant number of international collaboration } \\
\text { activities }\end{array}$ & $\begin{array}{l}\text { The continuity of the lack of evidence based } \\
\text { strategic planning at the level of research } \\
\text { performers. }\end{array}$ \\
\hline & \multirow[t]{2}{*}{$\begin{array}{l}\text { Emerging competencies in specific disciplines } \\
\text { especially in psychology, neuroscience, veterinary, } \\
\text { economics and social sciences. }\end{array}$} & $\begin{array}{l}\text { The continuation of establishing science parks } \\
\text { and research facilities that are not equipped } \\
\text { enough to perform the desired activities. }\end{array}$ \\
\hline & & $\begin{array}{l}\text { No specialized institute for science and } \\
\text { innovation policy }\end{array}$ \\
\hline & $\begin{array}{l}\text { Emerging initiatives that support innovation in rural } \\
\text { areas. }\end{array}$ & $\begin{array}{l}\text { Private universities are now allowed to undertake } \\
\text { postgraduate programs }\end{array}$ \\
\hline & \multirow{2}{*}{$\begin{array}{l}\text { Development of national technology platforms and } \\
\text { innovative business clusters. }\end{array}$} & The percentage of illiterate population \\
\hline & & $\begin{array}{l}\text { Scope of work inconsistence of the several } \\
\text { public administration actors with high } \\
\text { overlapping responsibilities. }\end{array}$ \\
\hline \multirow[t]{2}{*}{$\begin{array}{l}\text { Internationa } \\
1 \\
\text { perspective }\end{array}$} & $\begin{array}{l}\text { Good cooperation capacities with Europe and North } \\
\text { Africa in addition to growing demand of African } \\
\text { cooperation. }\end{array}$ & $\begin{array}{l}\text { The national political and security stability could } \\
\text { affect the research and innovation performance. }\end{array}$ \\
\hline & $\begin{array}{l}\text { Agriculture, food and medical research fields have } \\
\text { high potential for collaborative activities based on } \\
\text { bibliometric analysis. }\end{array}$ & $\begin{array}{l}\text { No significant presence in international } \\
\text { competitive research programs with less } \\
\text { representation in the mega scale project and } \\
\text { international consortiums. }\end{array}$ \\
\hline \multirow{4}{*}{$\begin{array}{l}\text { The use of } \\
\text { Intellectual } \\
\text { property } \\
\text { rights and } \\
\text { research } \\
\text { investment }\end{array}$} & $\begin{array}{l}\text { Good geographical coverage of technology transfer } \\
\text { offices among research performers and industry. }\end{array}$ & $\begin{array}{l}\text { The Egyptian industry lack of trust in the } \\
\text { scientific local expertise. }\end{array}$ \\
\hline & $\begin{array}{l}\text { Existence of mega scale projects like new suez } \\
\text { canal, Grain stock exchange and new valley } \\
\text { investments. }\end{array}$ & Less competitiveness in the international markets \\
\hline & $\begin{array}{l}\text { New investments opportunities in renewable energy } \\
\text { and transportation. }\end{array}$ & $\begin{array}{l}\text { Weak coordination measures between investment } \\
\text { and economic agencies with science and } \\
\text { technology agencies. }\end{array}$ \\
\hline & $\begin{array}{l}\text { Political support in optimizing the local } \\
\text { manufacturing and Egypt specialized industry like } \\
\text { textiles, pharmaceutics and petrochemicals. }\end{array}$ & $\begin{array}{l}\text { Insignificance of existing mechanisms to link } \\
\text { industry and academia }\end{array}$ \\
\hline
\end{tabular}

\section{Conclusions}

Egypt science and technology system was built few decades ago as static and linear system that doesn't allow quick adaptation to the current dynamics (Rezk et al., 2016; Radwan, 2015). Some authors have indicated that the non-linear and dynamic national systems could facilitate the technological development and allow better market uptake of research results, as well as boosting product innovation capabilities (Quitzow, 2015; Samara, Georgiadis, \& Bakouros, 2012). One main recommendation concluded from this study emphasizes on the importance of promoting evidence based strategic planning at the level of research institutions in Egypt. Many previous studies underscored the importance of evaluation and monitoring system of science and technology as essential component of the development process (Etzkowitz \& Leydesdorff, 2000; O’Brien et al., 2013). Having a continous and effective evaluation and monitoring mechanism embedded in the national system of scientce and 
ENTREPRENEURSHIP AND SUSTAINABILITY ISSUES

ISSN 2345-0282 (online) http://jssidoi.org/jesi/

2017 Volume 5 Number 2 (December)

http://doi.org/10.9770/jesi.2017.5.2(3)

technology is paramount for effective utlisation of existing capabilities and resources. The findings of the SWOT analysis of national systems would contribute in building the conceptual framework needed in further development of policies.

\section{References}

Becker, T. L. (2001). The comprehensive electronic town meeting and its role in 21st century democracy. Futures, 33(3-4), 347-350. http://dx.doi.org/10.1016/S0016-3287(00)00076-8

Bermejo Ruiz, J. M.; \& De Pablos-Heredero, C. (2013a). An Analysis of the Spanish Science and Technology System. Procedia Technology, 9(0), 511-517. http://dx.doi.org/10.1016/j.protcy.2013.12.057

Bermejo Ruiz; J. M., \& De Pablos-Heredero, C. (2013b). An Analysis of the Spanish Science and Technology System. Procedia Technology, 9(Supplement C), 511-517. https://doi.org/10.1016/j.protcy.2013.12.057

Charmaz, K.; \& Bryant, A. (2010). Grounded Theory A2 - Peterson, Penelope. In E. Baker \& B. McGaw (Eds.), International Encyclopedia of Education (Third Edition) (pp. 406-412). Oxford: Elsevier.

Etzkowitz, H.; Leydesdorff, L. (2000). The dynamics of innovation: from National Systems and "Mode 2" to a Triple Helix of universityindustry-government relations. Research Policy, 29(2), 109-123. http://dx.doi.org/10.1016/S0048-7333(99)00055-4

George, J. F.; Nunamaker, J. F.; Valacich, J. S. (1992). Electronic meeting systems as innovation: A study of the innovation process. Information \& Management, 22(3), 187-195. https://doi.org/10.1016/0378-7206(92)90071-M

George, J. F.; Nunamaker Jr, J. F.; Valacich, J. S. (1992). Electronic meeting systems as innovation: A study of the innovation process. Information \& Management, 22(3), 187-195. http://dx.doi.org/10.1016/0378-7206(92)90071-M

Ghinolfi, D.; El Baz, H. G.; Borgonovi, E.; Radwan, A.; Laurence, O.; Sayed, H. A.; Filipponi, F. (2014). A model for southern mediterranean research institute self-assessment: A SWOT analysis-based approach to promote capacity building at Theodor Bilharz Research Institute in Cairo (Egypt). Arab Journal of Gastroenterology, 15(3-4), 92-97. http://dx.doi.org/10.1016/j.ajg.2014.05.003

Kearns, K. P. (1992). Innovations in local government: A sociocognitive network approach. Knowledge and Policy, 5(2), $45-67$. http://dx.doi.org/10.1007/BF02692805

Melas, V.; Lisin, E.; Tvaronavičienė, M.; Peresadko, G.; Radwański, R. 2017. Energy security and economic development: renewables and the integration of energy systems, Journal of Security and Sustainability Issues 7(1), 133-139. https://doi.org/10.9770/jssi.2017.7.1(11)

O’Brien, K.; Reams, J.; Caspari, A.; Dugmore, A.; Faghihimani, M.; Fazey, I.; Winiwarter, V. (2013). You say you want a revolution? Transforming education and capacity building in response to global change. Environmental Science \& Policy, 28(0), 48-59. http://dx.doi.org/10.1016/j.envsci.2012.11.011

Organisation for Economic, C., \& Development. (2010). Measuring innovation: A new perspective (Vol. 9789264059474).

Phadermrod, B.; Crowder, R. M., \& Wills, G. B. (2016). Importance-Performance Analysis based SWOT analysis. International Journal of Information Management. https://doi.org/10.1016/j.ijinfomgt.2016.03.009

Rezk, M. A.; Ibrahim, H. H.; Radwan, A.; Sakr, M. M.; Tvaronavičienė, M.; Piccinetti, L. 2016. Innovation magnitude of manufacturing industry in Egypt with particular focus on SMEs, Entrepreneurship and Sustainability Issues 3(4), 307318. https://doi.org/10.9770/jesi.2016.3.4(1)

Quitzow, R. (2015). Dynamics of a policy-driven market: The co-evolution of technological innovation systems for solar photovoltaics in China and Germany. Environmental Innovation and Societal Transitions (0). http://dx.doi.org/10.1016/j.eist.2014.12.002

Radwan, A. (2015). Analytical view of national innovation ecosystem

https://www.unescwa.org/sites/www.unescwa.org/files/page_attachments/egypt_science_technology_and_innovation_landscape_analysis_ $\underline{0 . p d f}$ 
ENTREPRENEURSHIP AND SUSTAINABILITY ISSUES

ISSN 2345-0282 (online) http://jssidoi.org/jesi/

2017 Volume 5 Number 2 (December)

http://doi.org/10.9770/jesi.2017.5.2(3)

Samara, E.; Georgiadis, P.; Bakouros, I. (2012). The impact of innovation policies on the performance of national innovation systems: A system dynamics analysis. Technovation, 32(11), 624-638. http://dx.doi.org/10.1016/j.technovation.2012.06.002

Štiglic, D. 2017. Towards security through economic policy: a Baldwin's approach, Journal of Security and Sustainability Issues 7(1), 5565. https://doi.org/10.9770/jssi.2017.7.1(6)

Tvaronavičienė, M; Shishkin, A.; Lukáč, P.; Illiashenko, N., \& Zapototskyi, S. 2017. Sustainable economic growth and development of educational systems, Journal of International Studies, 10(3), 285-292. https://doi.org/10.14254/2071-8330.2017/10-3/21

\section{Aknowledgements}

This research was supported by the project, which has received funding from the European Union's Horizon 2020 research and innovation programme European Research Council (ERC) under the European Union's Horizon 2020 research and innovation programme Marie Sklodowska-Curie Research and Innovation Staff Exchanges ES H2020-MSCA-RISE-2014 CLUSDEVMED (2015-2019) Grant Agreement Number 645730730

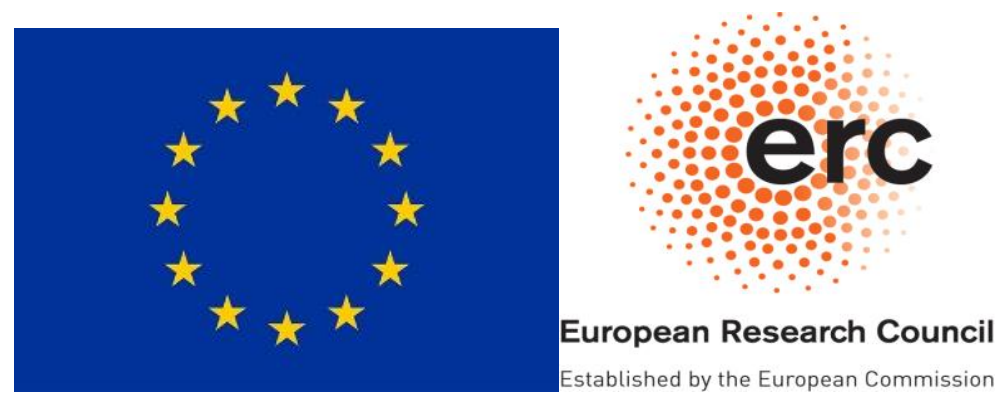

Amr RADWAN is the Head of Research and Innovation Management Department at the Egyptian Academy of Scientific Research \& Technology (ASRT). Amr has a number of published papers and reports in the area of innovation management, research governance, science policy and evidence-based medicine, and co-authored several strategies for S\&T. Before joining the Academy of Scientific Research in Egypt, he was a researcher at Unipharma pharmaceutical corp., where he also founded its process innovation unit. He has a pharmacology background with professional industry experience and has also obtained a Masters of Business Administration (MBA) and a number of diplomas in Intellectual Property Rights and Innovation Management.

ORCID ID: orcid.org/0000-0002-9667-3730

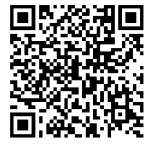

Register for an ORCID ID:

https://orcid.org/register

Copyright (C) 2017 by author(s) and VsI Entrepreneurship and Sustainability Center

This work is licensed under the Creative Commons Attribution International License (CC BY).

http://creativecommons.org/licenses/by/4.0/

cC) (7) Open Access 